\title{
INTEGRATED SUSTAINABLE MANGROVE FOREST MANAGEMENT
}

\author{
Pengelolaan Hutan Mangrove yang Berkelanjutan dan Terintegrasi
}

\author{
Cecep Kusmana \\ Departemen Silvikultur, Fakultas Kehutanan, Institut Pertanian Bogor, Kampus IPB Darmaga, Bogor 16680— \\ ckusmana@ymail.com
}

(Diterima: 10-07-2014; Disetujui: 11-08-2014)

\section{Introduction}

Mangrove is a saline swamp forest in tropical and sub-tropical intertidal regions. In Southeast Asia, the word mangrove is used for both individual plants and forest communities inhabiting tidal land. Mangroves are among the world's most productive ecosystems producing organic carbon well in excess of the ecosystem requirements and contribute significantly to the global carbon cycle (Kathiresan \& Bingham 2001). They protect coastline, enrich coastal waters, support coastal fisheries, yield beneficial forest products, serve as habitat for various kinds of fauna, and as sites for burgeoning ecotourism industry. Geographically, they are mainly distributed between $30^{\circ}$ North and $30^{\circ}$ South. Northern extension of this limit occur in Japan $\left(31^{\circ} 22^{\prime} \mathrm{N}\right)$ and Bermuda $\left(32^{\circ} 20^{\prime} \mathrm{N}\right)$; southern extensions are in New Zealand ( $\left.38^{\circ} 03^{\prime} \mathrm{S}\right)$, Australia $\left(38^{\circ}\right.$ $45^{\prime} \mathrm{S}$ ), and on the east coast of South Africa (Spalding 1997). A total of 124 countries and areas were identified as containing one or more true mangrove species (Saenger, Hegerl and Davie 1983). According to FAO (2007), some 15.2 million hectares of mangroves are estimated to exist worldwide as of 2005 , down from 18.8 million hectares in 1980 . To most extensive mangrove area is found in Asia, followed by Africa and North and Central America. Five countries (Indonesia, Australia, Brazil, Nigeria and Mexico) together account for 48 percent of the total global area, and 65 percent spread over 114 countries and areas, of which 60 have less than 10000 ha of mangroves each. Asia, which is the region with the lowest forest in terms of percentage of land area, has the largest extent of mangroves (approximately 6 million hectares), and five of ten countries with the largest extent of mangroves worldwide are found in this region.

For centuries, coastal people have traditionally utilized mangroves for subsistence purposes (Lacerda et al. 1993b), mainly firewood, charcoal tannin, dyes, food and beverages, medicines, poles, and timber. During the early stage of commercialization, fishing and charcoal making are generally the basic economic activities around the mangrove areas. However, in the following period, large scale commercial mangrove exploitation took place with production of logs, charcoal, and chipwoods.
Saenger (2002) noticeably reported that early views of mangroves during the modern era were largely based on ignorance, followed by the phase of enlightenment where mangroves were viewed as scientific curiosities which soon followed by early stage of commercial forest operations. This phase of ruthless exploitation, often through colonial administrations continued until 1930s. Following the war, there was a period of rebuilding followed by a renewed phase of environmental exploitation until the mid 1970s. In the late of 1970s to early 1980s, the gradual realization of mangroves and associated ecosystems based on a sustainable basis was come, but it came at the same time as the large scale development of industrial aquaculture, mainly for prawns. Since enacted of Rio Declaration on Environment and Development by UNCED at the year of 1992, sustainable forest management (SFM) concept has been strongly adopted until now in order to optimize the sustainable of economic, social and ecological functions of the forest ecosystems. So that, mangroves as almighty award must be utilized with the prudent management for the fullfill the needs and welfare of human being, harmonized with the other parts of ecosystem in which human resided.

\section{Reasons for Mangroves to be Managed}

Mangrove ecosystem is an interface unique ecosystem between marine and terrestrial ecosystems characterized by high productivity and rapid cycling of nutrients (Snedaker 1978) that contribute a major share of the energy requirements offshore ecosystems (Harger 1982). Therefore, they are considered as important natural resource for multiple reasons, especially for the tropical countries. Some of their functions are as follows:

(1) a protective barrier reducing coastal erosion, storm surges and a strong winds (Harger 1982; Saenger et al. 1983; Odum et al. 1982; Hamilton and Snedaker 1984)a spawning, feeding and nursery area for many economically important marine organisms especially fishes (Snedaker, 1978; Saenger et al., 1983; Harger, 1982; FAO, 1982)

(2) a habitat for wildlife such as birds, primates, amphibians, reptiles, mammals, etc. (Saengeret al. 
1983; Odumet al. 1982; FAO 1982, Tomlinson 1986; Macnae 1968)

(3) wood (timber, fuelwood, charcoal, pole, etc.) and minor forest products (tannin, honey, alcohol, food, drugs and beverages, medicine, etc.) (Snedaker 198; Harger 1982; Odum et al. 1982; FAO 1982; Saenger et al. 1983);

(4) valuable opportunities for education, scientific study and tourism (Saenger et al. 1983); and

(5) In Southeast Asia and the Pacific regions, the mangrove area is also used as reserved land for human resettlement, oil industry and fishpond (FAO 1982).

Generally speaking, mangrove resources to be managed of a region can be defined as consisting of (Saenger, Hegerl \& Davie 1983; Kusmana 1993):

(1) one or more plant species that are restricted to mangroves,

(2) plant species growing in mangroves and nonmangroves habitats,

(3) mangrove-associated biota (terrestrial and marine, tree moss, mushroom, algae, bacteria, etc.) that are permanent, semi-permanent, rarely occurring, frequent or restricted in mangroves habitat,

(4) dynamic processes that are important for ecosystem maintenance,

(5) mud flat found between forest fringes and the open sea, and

(6) population live in and/or surrounding mangroves.

The rate of disturbance and variety of the humaninduced influences on the mangrove ecosystems have been steadily increasing, so a large proportion of the World's mangrove is threatened with destruction. The main cause of the mangrove destruction as currently underway in the world can be broadly distinguished as: (1) over exploitation by the traditional users (e.g. for charcoal, pole and firewood) and uncontrolled forest concession airs, (2) destructive actions resulting from activities generally unrelated to sustained uses of mangroves (e.g. conversion to agriculture, mining/mineral extraction, aquaculture, etc.) (Saenger et al. 1983), and (3) pollution and natural disaster (Kusmana 2010). So that, the conversion of mangrove areas to other uses over the past decades has been alarming. For example, increasing population growth and economic development in Indonesia have resulted in the destruction even disappearances of many mangroves through land conversion to fishponds, industrial estates, transportation and recreation infrastructure, resettlement, tin mining, agricultural activities, and other land uses. Major exploitation and conversions have resulted in the destruction of more than $50 \%$ of Indonesian mangrove areas (Kusmana et al. 2008). However, FAO (2007) reported that although mangroves still face major threats, the rate of loss has recently been decreasing from some 187.000 ha lost annually in the $1980 \mathrm{~s}(-1,04$ percent per year) to 102.000 ha annually $(-0,66$ percent per year) during the 2000-2005 period. The figures suggest that during the past 25 years about 3,6 million hectares have been lost, corresponding to some 20 percent of the global mangrove area in 1980. At the regional level, Asia suffered the largest net loss: more than 1,9 million hectares since 1980, mainly due to changes in land use from 1980 to 1990. North and Central America and Africa also contributed significantly to its decrease in mangrove area at the global level, with losses of about 690.000 and 510.000 ha respectively over the last 25 years. Because of the important mangrove values/functions and its considerable losses around the world, mangroves are clearly need to be managed properly based on sustainable principle, if not they and their services will be lost.

\section{Mangrove Management Framework}

As an interface ecosystem between marine and terrestrial ecosystem, mangroves as one of renewable resources must be considered as an integral component of a complex coastal ecosystems simultaneously an integral component of a water catchment area. So that, decisions regarding to the utilization of mangroves must be constructed in the proper view of mangrove dependency on land use in the water catchment and on the important interrelationships of mangroves with estuaries, seagrass bed and coral reefs. Management within those physical boundaries must proceed primarily on an ecological basis. After the ecological factor have been adequately assessed, however, that other factors, be they economic, social or political, should be brought into focus (Saenger 2002; Kusmana 2010). Dahuri et al. (2001) describe the relationship between upland (catchment area) and coastal ecosystem as noticed on Figure 1.

As a renewable resource, mangroves have to be managed on a sustainable basis.In regarding to the management of mangroves, there are some valuable suggestions from Saenger (2002) such as follows:

"Management of mangroves must be based on a philosophy of conservation which, as a first step, seeks to prevent further destruction of existing mangrove ecosystems. Most importantly, it should recognize the need to devise management practices which optimize the conservation of mangrove resources in such a way as to provide for traditional and contemporary human needs, while ensuring adequate provision of reserves suitable for protection of diversity of plant and animal life within them. The concept of sustainable economic returns, and at the same time maintaining the ecosystem as close to its natural or original state as possible. This is difficult to attain except in a few cases such as use for tourism. Consequently, sustainable use often does not mean the original natural system in its pristine condition: a compromise may be reached which allows sustainable yield and reasonable resemblance to an undisturbed or non-harvested system.However, preservation or maintaining a completely undisturbed or unexploited state may be a desirable management policy for certain localities or for some parts of extensive mangroves. Such exploited areas serve as a refuge for fauna and flora and as a biological resource 
for restoring areas in which management policies have failed or accidents have occurred. Preservation of some proportion of a mangrove area can buffer the area generally and can be an advantageous part of an overall sustained-use management plan."

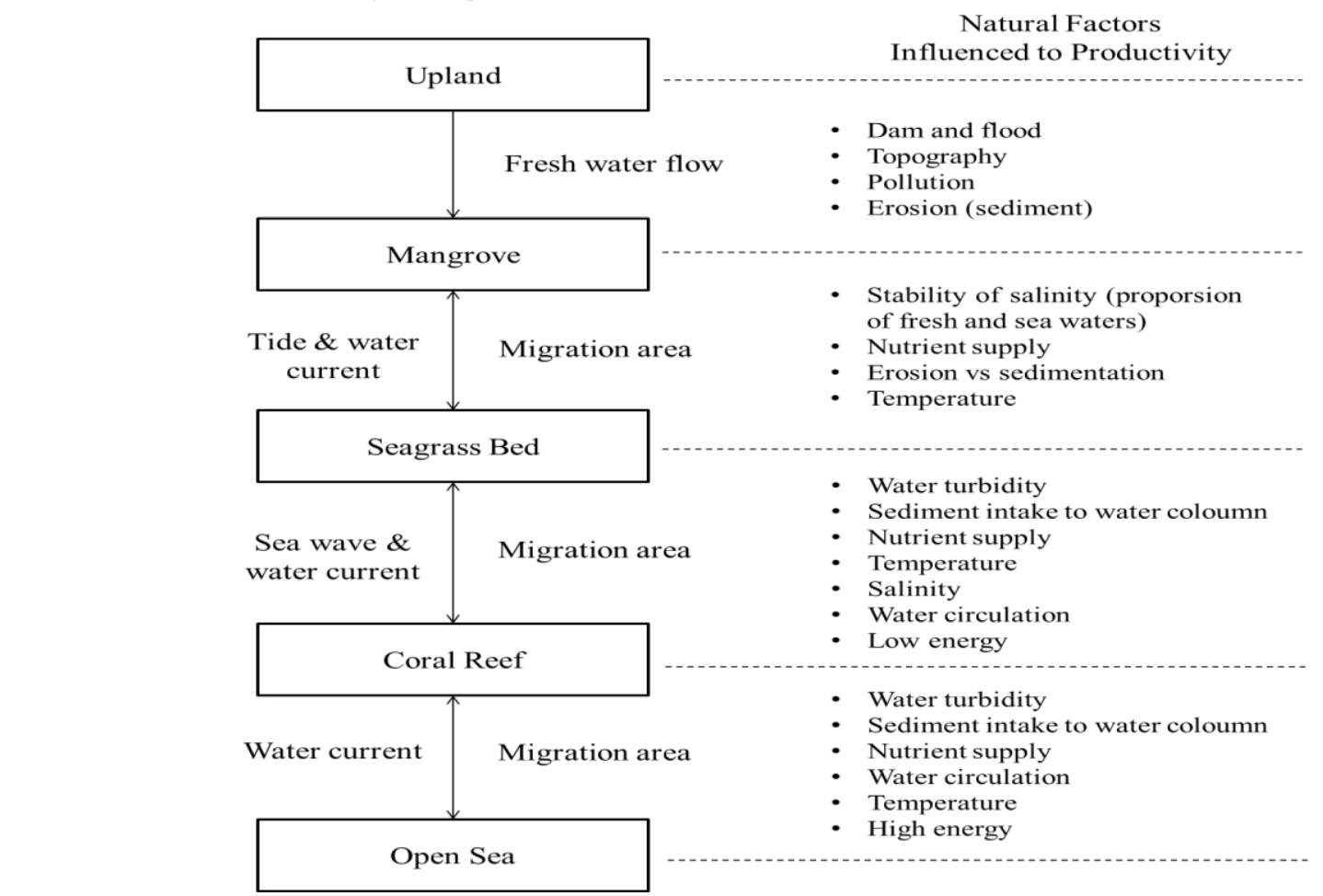

Fig. 1. Interconnection between upland catchment area and coastal ecosystem
It needs a proper management zoning to harmonized the mangrove allocation for preservation, conservation and intensive developments.

\section{4. "Sustainable" and "Integrated" Meaning Reagarding to Mangrove Management}

\section{1. "Sustainable"}

There are two extreme options of mangrove ecosystem management, such as: (1) mangrove to be managed as protected area without any utilization action, and (2) mangrove to be converted to other unsustained uses (agriculture, resettlement, airport, marinas, roads, etc.). In between these two extreme options of management lie additional alternative management option of mangrove, what we called sustainable mangrove forest management (SFM) such as for woods and nonwood forest products, ecotourism, agroforestry (i.e. silvofishery, agrosilvopastural system, etc). So that, as a renewable resource, mangroves, which having various valuable products and environmental services, must be managed on a sustainable basis. It means the viewed of all mangrove functions regarding to the ecological, economical, and social benefits have the equity concern. Concerning to the sound of sustainable principle, the objective of the forest management is to obtain the sustain optimalization among economic, social, and ecological benefits from the forest ecosystem in order to fulfill the needs of recent generation without reduction option uses as well as the needs of future generation.

ITTO (1998) stated that sustainable forest management (SFM) is the process of managing forest to achieve one or more clearly specified objectives of management with regard to the production of a continuous flow of desired forest products and services without undue reduction of its inherent values and future productivity and without undue undesirable effects on the physical and social environment. The similar manner stated by Helsinki (1993) in Suhendang (2002) that SFM is the stewardship and use of forest and forestlands in way, and at rate, that maintains their biodiversity, productivity, regeneration capacity, vitality, and potential to fulfill, now and in the future, relevant ecological, economic, and social functions at local, national, and global levels, and that does not cause damage to other ecosystems. The SFM itself needs the prudent process of forest planning, utilization, rehabilitation/restoration, protection and conservation, proper controlling, and law enforcement. Munasinghe (2003) stated that sustainable development consisting of three pillars which is interconnection and possible feedbacks into one story, such as economic, social, and ecological pillars (Figure 2). 


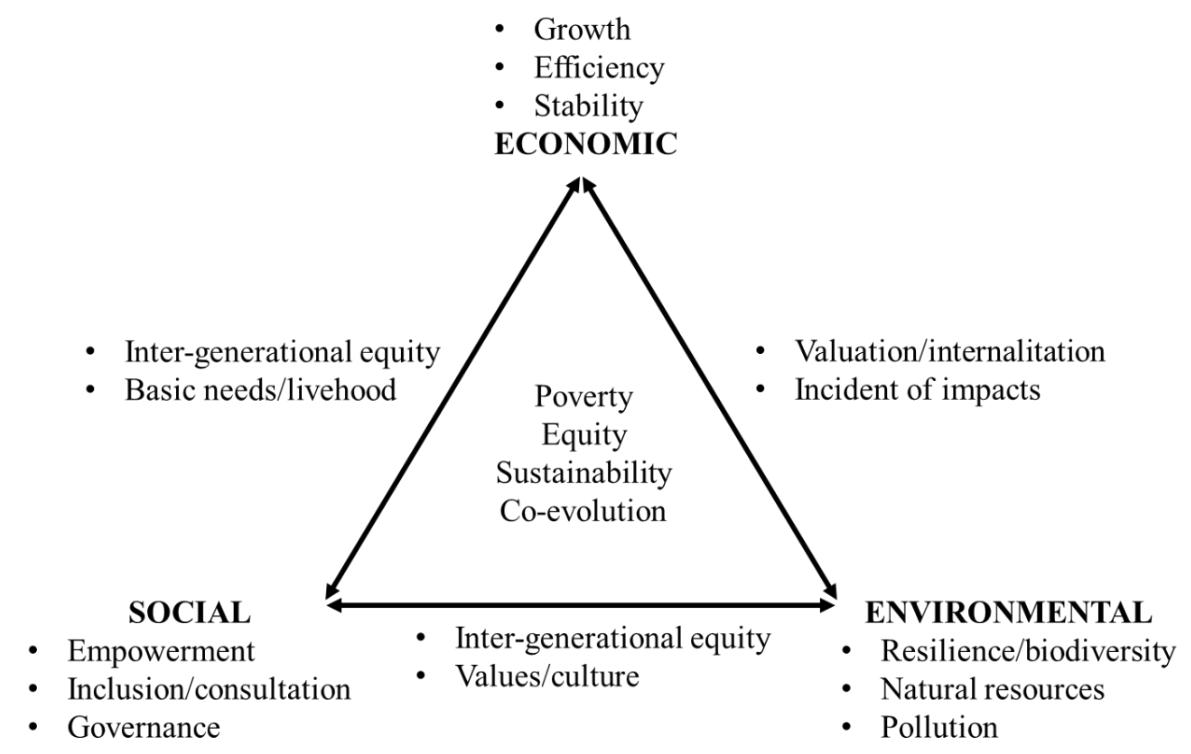

Fig. 2. Three pillars of sustainable development

It In term of mangrove forest management, those pillars have the concerns such as follows:

(a) Ecological pillar regards to maintain the existence, biodiversity, function and productivity as well as the carrying capacity of mangrove ecosystem. Besides, the effort of rehabilitation/restoration for destroyed mangrove areas and protection/preservation for undisturbed (pristine) mangrove as well as fragile habitats.

(b) Social pillar regards to the perception, understanding, attitude, and behavior of the community to the existence, status, values and functions of mangroves. It is also regarding to the local community empowerment in mangrove management.

(c) Economic pillar regards to the diverse utilization of mangrove ecosystem for various valuable products (woods and non-wood forest products), aesthetic and other environmental services.

For running optimize among three pillars needs the proper institutional and regulations which the concern such as follows:

(a) Institutional takes a concern to strengthen the capacity building of central and local government as well as community; to strengthen the role of management authority and scientific authority; and to well develop the collaboration, coordination and sinergizationamong stakeholders.

(b) Regulations concern to firmly the policies regarding the sustainable mangrove forest management; strengthen mangrove forest status on a coastal spatial planning of a region; and law enforcement and obedient to the regulations regarding to mangrove forest management.

The concept of sustainability (i.e. sustainable mangrove forest management) requires tools to ensure a balance between economic, social and ecological dimensions of development. It provides the overarching goals wanted by society, but they are difficult to measure (Vogt et al. 2010).
Some tools have been developed to measure the performance of Sustainable Forest Management (SFM) including mangrove forest are:

(a) ITTO's Criteria for the Measurement of Sustainable Tropical Forest Management (ITTO, 1992) which was developed to ITTO's Criteria and Indicators for Sustainable Forest Management of Natural Tropical Forest (ITTO, 1998) consisting of seven criteria such as:

(1) enabling conditions for SFM,

(2) forest resource security,

(3) forest ecosystem health and condition,

(4) flow of forest produce,

(5) biological diversity,

(6) soil and water,

(7) economic, social and cultural aspects.

(b) Principle and Criteria for Forest Stewardship (FSC, 1999) consisting of 10 principles and 55 criteria, such as:

(1) Compliance with law and FSC principles (6 criteria)

(2) Tenure and use rights and responsibilities (3 criteria)

(3) Indigenous people rights (4 criteria)

(4) Community relations and worker's right (5 criteria)

(5) Benefit from the forest (6 criteria)

(6) Environment impact (10 criteria)

(7) Management plan (4 criteria)

(8) Monitoring and assessment (5 criteria)

(9) Maintenance of high conservation value forest (4 criteria),

(10) Plantations ( 8 criteria)

(c) LEI's Indicator Intensity Scale for Sustainable Production Natural Forest (LEI 1999) consisting of the aspects of production, ecology and social sustainability.

(d) Ministry of Forestry's Criteria and Indicator of Sustainable Production Natural Forest (MoF 1993) 
consisting the aspects of forest resources, sustained-yield, conservation, social-economic and institutional.

(e) CIFOR's Criteria and Indicator for Assessing the Sustainability of Forest Management: Conservation of Biodiversity (Stork et al. 1997)

(f) CIFOR's Principles, Criteria and Indicators: Applying Ockham's Razor to the People-Forestry Link (Colfer with Prabhu and Wollenberg 1995)

CIFOR's Testing Criteria and Indicators for Assessing the Sustainability of Forest Measurement: Genetic Criteria and Indicators (Namkoong et al. 1996).

\section{2. "Integrated"}

The meaning of "integrated" word regarding to mangrove forest management relates five dimensions, such as:

(1) Knowledge

The management of mangroves needs interdiciplinary approach relates various diciplines (ecology, economy, sociology, technique, law, and other relevance diciplines).

(2) Technical consideration

In managing a mangrove ecosystem, considerations of economic, social culture, and environment (ecology) should be brought into focus in balance simultaneously.

(3) Coordination

Harmonized collaboration among stakeholders (government, private, community) regarding to mangrove ecosystem management should be constructed. In term of government which relates many sectors, should be a good coordination among them concerning duty, authority and responsibility, either for horizontal sector integration or vertical one.

(4) Consultative

Mangrove forest management practices should be constructed from the needs and aspiration of all stakeholders strating from the processes of planning until implementation as well as monitoring and evaluation. The last process give chance to the manager do early correction to management practices in order to obtain the goal of mangrove ecosystem management agreed by stakeholders.

(5) Ecological inter-relationship

Mangrove is an integral part of the complex coastal ecosystems consisting of estuary, coral reef, seagrass bed, and other agro-complex ecosystems. Beside, mangroves are also significantly influenced by both natural process and human activities coming from upland and oceans. So that, a mangrove ecosystem management practice must be considered those ecological inter-connection among those ecosystems.

\section{Conclusion}

Mangrove forest as a renewable resource must be managed based on sustainable basis in which the benefits of ecological, economic and social from the forest have to equity concern in achieving the optimum forest products and services in fulfill the needs of recent generation without destruction of future generation needs and that does not undesirable effects on the physical and social environment. This Sustainable Forest Management (SFM) practices needs the supporting of sustainability in the development of social, economic and environment (ecological) sounds simultaneously, it should be run by the proper institutional and regulations. In operational scale, SFM need integration in terms of knowledge, technical, consultative of stakeholders, coordination among sectors and other stakeholders, and considerations of ecological inter-relationship in which mangroves as an integral part of both a coastal ecosystem and a watershed (catchment area). Some tools have been developed to measure the performent of SFM, such as initiated by ITTO at 1992 and followed by Ministry of Forestry of Indonesia (1993), CIFOR (1995), LEI (1999), FSC (1999), etc., however, the true nuance of SFM's performance is not easy to be measured.

\section{Reference}

[1] Colfer, C. J. P., R. Prabhu, E. Wollenberg, 1995. Principles, criteria and indicators: applying ockham's razor to the people-forestry link. Working Paper No. 8. Center for International Forestry Research, Bogor.

[2] Dahuri, R., J. Rais, S. P. Ginting, M. J. Sitepu, 2001. Pengelolaan Sumber Daya Wilayah Pesisir dan Lautan secara Terpadu. PT Pradnya Paramita, Jakarta.

[3] [FAO] Food and Agriculture Organization of the United Nations,1982. Management and utilization of mangroves in Asia and the Pacific. FAO Environmental Paper 3, FAO, Rome.

[4] [FAO] Food and Agriculture Organization of the United Nations, 2007. The World's Mangrove 1980-2005. Food and Agriculture Organization of the United Nations, Rome.

[5] [FSC] Forest Stewardship Council, 1999. Document 1.2. Principles and Criteria for Forest Stewardship. FSC, A.C., Oaxaca, Mexico.

[6] Hamilton, L. S., S. C. Snedaker (eds.), 1984. Handbooks for mangrove areas management. IUCN-UNESCO, pp. 123.

[7] Harger, J. R. E., 1982. Major problems in the functional analysis of mangroves in Southeast Asia. Paper presented at the symposium on mangrove forest ecosystem productivity, April 20-22, 1982, Bogor.

[8] [ITTO] International Tropical Timber Organization, 1992. Criteria for the Measurement of Sustainable Tropical Forest Management. ITTO Policy Development Series No. 3 ITTO, Yokohama.

[9] [ITTO] International Tropical Timber Organization, 1998. Criteria and Indicators for Sustainable Management of Natural Tropical Forest. ITTO Policy Devlopment Series No. 7. ITTO, Yokohama.

[10] Kathiresan, K., B. L. Bingham, 2001. Biology of mangroves and mangrove ecosystems. Advance in Marine Biology 40, pp. 81-251. 
[11] Kusmana, C., 1993. A Study on Mangrove Forest Management Based on Ecological Data in East Sumatra, Indonesia. PhD. Dissertion, Kyoto University, Japan.

[12] Kusmana, C., Istomo, C. Wibowo, S.W. Budi, I.Z. Siregar, T. Tiryana, S. Sukardjo, 2008. Manual of Mangrove Silviculture in Indonesia. Korea International Cooperation Agency (KOICA), Jakarta.

[13] Kusmana, C., Istomo, C. Wibowo, S.W. Budi, I.Z. Siregar, T. Tiryana, S. Sukardjo,2010. Konservasi dan Pengelolaan Mangrove. Presented on: Konferensi dan Pameran Nasional "Penyelamatan Hutan Pantai dan Peningkatan Kesejahteraan Masyarakat Pesisir", 23 November 2010.

[14] Lacerda, L. D., J. E. Conde, C. Alarcon, R. Alvarez-León, P. R. Bacon, L. D’Croz, B. Kjerfve, J. Polania, M. Vannucsi, 1993. Mangrove ecosystems of Latin America and the Caribbean: a summary. In: Lecarda, L.D (Ed.), Conservation and sustainable utilization of mangrove forest in Latin America and Africa regions. Part I - Latin America. ITTO/ISME, Okinawa, pp. 1-42.

[15] [LEI] Lembaga Ekolabel Indonesia, 1999. Skala intensitas indikator pengelolaan hutan alam produksi lestari, Pedoman LEI-02. Lembaga Ekolabel Indonesia, Jakarta.

[16] Macnae, W., 1968. A general account of the fauna and flora of mangrove swamps and forests in the Indowest-Pacific region. Adv. Mar. Biol. , pp. 73-270.

[17] Munasinghe, M., 1993. Environmental Economics and Sustainable Development. World Bank Environment Paper No. 3. Washington DC.

[18] [MoF] Ministry of Forestry Republic of Indonesia, 1993. Keputusan Menteri Kehutanan Nomor 252/Kpts-II/93 tentang Kriteria dan Indikator Pengelolaan Hutan Produksi Alam Indonesia secara Lestari, Jakarta.

[19] Namkoong, G., T. Boyle, H.R. Gregorius, H. Joly, O. Savolainen, W. Ratnam, A. Young, 1996. Testing Criteria and Indictors for Assessing the Sustainability of Forest Management: Genetic Criteria and Indicators. Working Paper No. 10. Center for International Forestry Research, Bogor.

[20] Odum, W. E., C. C. McIvor, T. J. Smith, 1982. The ecology of the mangroves of South Florida: a community profile. U.S. Fish and Wildlife Service, Office of Biological Services, Washington D.C.

[21] Saenger, P., E. J. Hegerl, J. D. S. Davie, 1983. Global status of mangrove ecosystems. IUCN. Comision on Ecology Number 3.

[22] Saenger, P., 2002. Mangrove Ecology, Silviculture and Conservation. Kluwer Academic Publishers, Netherlands.

[23] Snedaker, S. C., 1978. Mangroves: Their value and perpetuation. Nature and Resources 14, pp. 6-13.

[24] Stork, N. E., T. J. B. Boyle, V. Dale, H. Eeley, B. Finegan, M Lawes, N. Manokaran, R. Prabhu, J. Soberon, 1997. Criteria and indicators for assessing the sustainability of forest management: conservation of biodiversity. Working Paper No. 17. Center for International Forestry Research, Bogor.

[25] Suhendang, E., 2002. Pengantar Ilmu Kehutanan. Yayasan Penerbit Fakultas Kehutanan IPB, Bogor.

[26] Tomlinson, P. B., 1986. The Botany of Mangroves. Cambridge University Press, Cambridge.

[27] Vogt, K. A., T. Patel-Weynand, M. Shelton, D.J. Vogt, J.C. Gordon, C.T. Mukumoto, A.S. Suntana, P.A. Roads, 2010. Sustainability Unpacked: Food, Energy and Water for Resilient Environments and Societies. Earthscan, Washington DC. 